\title{
Effect of Season and Period of Milking on Milk Constituents of Sahiwal Cow in the High Humid Condition of Assam
}

\author{
Upasana Baruah $^{1 *}$, Purabi Kaushik ${ }^{2}$, Farzin Akhtar ${ }^{3}$ and Kabita Bala Kalita ${ }^{4}$ \\ ${ }^{1}$ Department of Animal Genetics and Breeding, College of Veterinary Science, Khanapara, Guwahati, Assam Agricultural \\ University, Jorhat, Assam, INDIA \\ ${ }^{2}$ Department of Instructional Livestock Farm Complex (AGB), College of Veterinary Science, Khanapara, Guwahati, \\ Assam Agricultural University, Jorhat, Assam, INDIA \\ ${ }^{3}$ Goat Research Station, Byrnihat, INDIA \\ ${ }^{4}$ Department of Animal Biotechnology, College of Veterinary Science, Khanapara, Guwahati, Assam Agricultural University, \\ Jorhat, Assam, INDIA \\ *Corresponding author: U Baruah; E-mail: upasanabaruah1994@gmail.com
}

Received: 13 May, 2021

Revised: 19 June, 2021

Accepted: 02 July, 2021

\begin{abstract}
Data on 3908 milk records of Sahiwal cows recorded over a period of 11 months were utilized for the study. The cows were reared at Sahiwal cattle farm, College of Veterinary Science, Assam Agricultural University, Khanapara, Guwahati, India. The least-squares mean and standard errors for fat, solid not fat, protein, and density were reported to be $4.42 \pm 0.02 \%, 8.45 \pm 0.01 \%$, $3.23 \pm 0.01 \%$ and $29.34 \pm 0.04 \mathrm{~kg} / \mathrm{m}^{3}$, respectively. Analysis of the variance revealed that season had a highly significant effect $(\mathrm{P}<0.01)$ on the fat, solid not fat and on the protein percentage but there was no significant effect of season on the density of milk. Again, a period of milking was reported to produce highly significant effects $(\mathrm{P}<0.01)$ on fat, solid not fat, protein, and milk density.
\end{abstract}

\section{HIGHLIGHTS}

(0 Highly significant effect of season and milking period on fat, SNF and protein.

(0 Milk fat, SNF and protein highest in winter season.

(0 Milk density highest in pre-monsoon season.

Keywords: Density, fat, protein, Sahiwal, solid not fat

In the global map, India as a nation is picturized for its diverse social, economical, and cultural environment. There is always a high demand for the animal sector in such land where more than $70 \%$ of people rely on agriculture. India is the largest producer of milk around the globe. Basic animal husbandry statistics generated by the Department of Animal Husbandry, Dairying and Fisheries, Ministry of Agriculture and Farmers Welfare, Government of India revealed that milk production in India during 1950-51 was 17 million tonnes which were recorded to be the highest during 2018-19; 187.7 million tonnes. The demand for milk in the north-eastern part of India, in particular, Assam has changed from 0.682 million tonnes to 0.882 million tonnes from 2001-02 to 2018-19.
The per capita availability of milk in our country was 130 grams per day during the period 1950-51 which was increased to 394 grams per day during 2018-2019 (Basic Animal Husbandry Statistics-2019).

The per capita availability of milk in Assam was recorded as 70 gram per day during 2001-02 and receives a slight change of 71 gram per day up to 2018-19. In recent years, awareness amongst people for the consumption of pure,

How to cite this article: Baruah, U., Kaushik, P., Akhtar, F. and Kalita, K.B. (2021). Effect of Season and Period of Milking on Milk Constituents of Sahiwal Cow in the High Humid Condition of Assam. J. Anim. Res., 11(04): 725-728.

Source of Support: None; Conflict of Interest: None 
clean, and hygienic milk has gained a special momentum. This leads to building a market of high economic income. Sahiwal is a milch breed, can contribute immensely by producing a higher amount of milk. This makes shifting of breeders and producers towards the idea of raising the purebred cows. This study aimed to get an idea about the performance of Sahiwal cows outside their original habitat, specifically in the high humid region of Assam to familiarize the producers and farmers of this region beforehand.

\section{MATERIALS AND METHODS}

The present study was approved by the Institutional Animal Ethics Committee. Animals were maintained with proper care and no harm was done. Milk samples were collected from each cow during both morning and evening periods of milking from the Sahiwal cattle farm, College of Veterinary Science, Assam Agricultural University, Khanapara, Guwahati for about 11 months, which is from May 2019 to January 2020. A total of 3908 numbers of records referring to 18 numbers of adult Sahiwal cows were utilized for the present study. The entire period was divided into 4 seasons viz. pre-monsoon season (S1: March-May), monsoon season (S2: June-September), post-monsoon season (S3: October-November) and winter season (S4: December-February). The main aim of maintaining the purebred of Sahiwal cow outside their breeding tract is to propagate them and use them for genetic up-gradation of local cattle in the high humid region of northeast east, in particular Assam.

The data for milk constituents such as fat, SNF (Solid Not Fat), protein and density of milk samples were analyzed.

Proper cleaning and sanitization of the cow udder and milking utensils, about $10 \mathrm{ml}$ of milk were collected from each cow in sterilized milk containers excluding the fore and residual milk and allowed to rest for about 1 hour to bring down the sample temperature into a normal range. Each milk sample was analyzed with the help of milk quality analyzer machine Laktan 1- 4 (Swathi et al., 2017). The same procedure was followed for both morning and evening milking sessions to determine the quality of milk.

\section{Statistical analysis}

The effects of season and period of milking on milk constituents were studied by the least squares analysis of variance using software package by Harvey (1975), suitable for non-orthogonal data. The comparisons among the means were carried out by Duncan's Multiple Range Test (DMRT) as modified by Kramer (1957).

\section{RESULTS AND DISCUSSION}

The overall least-squares means and standard errors for fat, solid not fat, protein and density were recorded as $4.42 \pm 0.02 \%, 8.45 \pm 0.01 \%, 3.23 \pm 0.01 \%$ and $29.34 \pm$ $0.04 \mathrm{~kg} / \mathrm{m}^{3}$, respectively (Table 1 ).

Table 1: Least squares mean (LSM) with standard errors (SE) and DMRT results for factors affecting different milk constituents during different seasons and different periods of the day

\begin{tabular}{|c|c|c|c|c|c|c|}
\hline \multirow{2}{*}{ Effects } & & \multirow{2}{*}{$\mathbf{N}$} & \multicolumn{4}{|c|}{$\mathbf{L S M} \pm \mathbf{S E}$} \\
\hline & & & Fat & SNF & Protein & Density \\
\hline$\mu$ & & 3908 & $\begin{array}{l}4.42 \pm \\
0.02\end{array}$ & $\begin{array}{l}8.45 \pm \\
0.01\end{array}$ & $\begin{array}{l}3.23 \pm \\
0.01\end{array}$ & $\begin{array}{l}29.34 \pm \\
0.04\end{array}$ \\
\hline \multirow{4}{*}{ Season } & S1 & 1066 & $\begin{array}{l}4.45 \pm \\
0.03^{\mathrm{a}} \\
\end{array}$ & $\begin{array}{l}8.48 \pm \\
0.02^{\mathrm{a}} \\
\end{array}$ & $\begin{array}{l}3.16 \pm \\
0.01^{\mathrm{a}} \\
\end{array}$ & $\begin{array}{l}29.43 \pm \\
0.07\end{array}$ \\
\hline & S2 & 1572 & $\begin{array}{l}4.28 \pm \\
0.02^{\mathrm{b}} \\
\end{array}$ & $\begin{array}{l}8.37 \pm \\
0.01^{b} \\
\end{array}$ & $\begin{array}{l}3.21 \pm \\
0.01^{\mathrm{b}} \\
\end{array}$ & $\begin{array}{l}29.24 \pm \\
0.05\end{array}$ \\
\hline & S3 & 698 & $\begin{array}{l}4.36 \pm \\
0.03^{\mathrm{c}}\end{array}$ & $\begin{array}{l}8.39 \pm \\
0.02^{\mathrm{c}}\end{array}$ & $\begin{array}{l}3.26 \pm \\
0.02^{\mathrm{c}}\end{array}$ & $\begin{array}{l}29.28 \pm \\
0.08\end{array}$ \\
\hline & S4 & 572 & $\begin{array}{l}4.60 \pm \\
0.04^{d}\end{array}$ & $\begin{array}{l}8.57 \pm \\
0.02^{d}\end{array}$ & $\begin{array}{l}3.27 \pm \\
0.02^{\mathrm{c}}\end{array}$ & $\begin{array}{l}29.42 \pm \\
0.09\end{array}$ \\
\hline \multirow{2}{*}{$\begin{array}{l}\text { Period } \\
\text { (M/E) }\end{array}$} & M & 1954 & $\begin{array}{l}4.11 \pm \\
0.02^{\mathrm{a}}\end{array}$ & $\begin{array}{l}8.16 \pm \\
0.01^{\mathrm{a}}\end{array}$ & $\begin{array}{l}3.09 \pm \\
0.01^{\mathrm{a}}\end{array}$ & $\begin{array}{l}28.66 \pm \\
0.05^{\mathrm{a}}\end{array}$ \\
\hline & E & 1954 & $\begin{array}{l}4.73 \pm \\
0.02^{b}\end{array}$ & $\begin{array}{l}8.75 \pm \\
0.01^{b}\end{array}$ & $\begin{array}{l}3.36 \pm \\
0.01^{b}\end{array}$ & $\begin{array}{l}30.02^{ \pm} \\
0.05^{\mathrm{b}}\end{array}$ \\
\hline
\end{tabular}

Least squares mean (LSM) for the factors with different superscripts differ significantly $(\mathrm{P}<0.05)$.

N: Number of observations; SE: Standard error; S1: Pre-monsoon season; S2: Monsoon season; S3: Post-monsoon season; S4: Winter season; M: Morning milking; E: Evening milking.

A similar value of fat \% was observed in Sahiwal cows $(4.89 \pm 1.5 \%)$ and Jersey $\times$ Sahiwal crossbred cows $(4.48 \pm 0.18 \%)$ by Reddy et al. (2015); in Holstein Friesian crossbred cows $(4.33 \pm 0.02 \%)$ by Sourabh et al. (2017). Some researchers also found lower values for the percentage of milk fat in Sahiwal cow. It was $3.98 \pm$ $0.16 \%$ as demonstrated by Chakravarthi et al. (2017). In the Sahiwal-Friesian crossbred cow, the fat percentage was reported to be 3.96-4.50\% (Talukder et al., 2013). 
The percentage of solid not fat (SNF) was calculated by different workers and varied results have their importance in their field of work. A lower value was observed by Chakravarthi et al. (2017) in Sahiwal cows $(8.36 \pm 0.05 \%)$ whreas Reddy et al. (2015) reported relatively higher SNF $\%$ of around 9 percent. Sourabh et al. (2017) and Reddy et al. (2015) observed quite similar values which were such that $8.29 \pm 0.01 \%$ for Holstein Friesian crossbred cows and $8.62 \pm 0 \%$ for Jersey $\times$ Sahiwal crossbred cows, respectively. Similar values were found by Talukder et al. (2013) in Sahiwal-Friesian crossbred cows.

Aslam et al. (2014) and Abraham and Gayathri (2015) reported similar values of protein $\%$ in Sahiwal cows being $3.35 \pm 0.06 \%$ and $3.04 \pm 0.04 \%$, respectively. Sourabh et al. (2017) observed lower protein percentage of $2.99 \pm$ 0.05 in Holstein Friesian crossbred cattle.

\section{Effect of season}

Analysis of the variance technique (Table 2) revealed that season had a highly significant effect $(\mathrm{P}<0.01)$ on the fat, solid not fat, and the protein percentage but there was no significant effect of season on the density of milk. Least squares means and standard errors were calculated separately for the four seasons in such a way that for fat, the values were $4.45 \pm 0.03 \%, 4.28 \pm 0.02 \%$, $4.36 \pm 0.03 \%$, and $4.60 \pm 0.04 \%$ in pre-monsoon season (S1), monsoon season (S2), post-monsoon season (S3) $\&$ winter season (S4), respectively. Means for SNF were $8.48 \pm 0.02 \%, 8.37 \pm 0.01 \%, 8.39 \pm 0.02 \%$ and $8.57 \pm$ $0.02 \%$ in S1, S2, S3 and S4 seasons, respectively. In case of protein estimation, these values were $3.16 \pm 0.01 \%$, $3.21 \pm 0.01 \%, 3.26 \pm 0.02 \%$ and $3.27 \pm 0.02 \%$ in S1, S2, S3 and S4 seasons, respectively. Again, after estimating density, these were $29.43 \pm 0.07 \mathrm{~kg} / \mathrm{m}^{3}, 29.24 \pm 0.05 \mathrm{~kg} /$ $\mathrm{m}^{3}, 29.28 \pm 0.08 \mathrm{~kg} / \mathrm{m}^{3}$ and $29.42 \pm 0.09 \mathrm{~kg} / \mathrm{m}^{3}$ in $\mathrm{S} 1, \mathrm{~S} 2$,
S3 \& S4 seasons, respectively. The percentage of fat and SNF were found to be the highest in the winter season and the lowest in the monsoon season. Again, the percentage of protein was found to be the highest in the winter season and the lowest in the pre-monsoon season. The density of milk was the highest during the pre-monsoon season and it the lowest during monsoon season.

The impact of seasons on milk compositions was demonstrated by different workers differently. Froidmont et al. (2013) demonstrated that fat and protein content in Holstein Friesian cattle milk was higher in the summer season and was least in the winter season. Fat content was lower in summer and protein content was generally high during the colder season and low in dry or hot season as reported by Arora and Bhojak (2013). In another study, Thomas and Sasidharan (2015) reported that the season had a highly significant influence $(\mathrm{P}<0.01)$ on milk composition traits of dairy cattle in humid tropics.

\section{Effect of period of milking}

Least squares analysis of variance (Table 2) revealed that the period of milking had a highly significant effect $(\mathrm{P}<0.01)$ on the fat, solid not fat, protein percentage, and on the density of milk. The least-squares means of fat were $4.11 \pm 0.02 \%$ in the morning and $4.73 \pm 0.02 \%$ in the evening. The values were $8.16 \pm 0.01 \%$ and 8.75 $\pm 0.01 \%$ for SNF; $3.09 \pm 0.01 \%$ and $3.36 \pm 0.01 \%$ for protein and $28.66 \pm 0.05 \mathrm{~kg} / \mathrm{m}^{3}$ and $30.02 \pm 0.05 \mathrm{~kg} / \mathrm{m}^{3}$ for density in the morning and evening, respectively. In this study, different milk constituents depicted higher values in the evening period than that of the morning period. Tona et al. (2013) noted that the average morning, evening, and total daily milk ranged from 9.37 to 12.67 $\%$ in the case of protein and 4.83 to $6.07 \%$ in the case of milk fat. The effect of feeding time on milk composition

Table 2: Analysis of variance showing effects of season and period of milking on fat, SNF, protein percentages and density $\left(\mathrm{kg} / \mathrm{m}^{3}\right)$ in the milk

\begin{tabular}{llllllllll}
\hline \multirow{2}{*}{ Sources of variation } & \multirow{2}{*}{ DF } & \multicolumn{2}{c}{ FAT } & \multicolumn{2}{c}{ SNF } & \multicolumn{2}{c}{ Protein } & \multicolumn{2}{c}{ Density } \\
\cline { 2 - 9 } & & MSS & F & MSS & F & MSS & F & MSS & F \\
\hline Season & 3 & 16.87 & $20.40^{* *}$ & 7.20 & $20.89^{* *}$ & 2.34 & $14.53^{* *}$ & 9.16 & $1.91^{\text {NS }}$ \\
\hline Period of milking & 1 & 373.02 & $451.11^{* *}$ & 335.02 & $972.10^{* *}$ & 74.61 & $463.40^{* *}$ & 1803.32 & $376.72^{* *}$ \\
\hline Error & 3903 & 0.83 & & 0.34 & & 0.16 & & 4.79 & \\
\hline
\end{tabular}

${ }^{* *} \mathrm{P}<0.01,{ }^{\text {NS. }}$ Not significant, DF: Degree of freedom, MSS: Mean Sum of Square. 
during the summer season was such that the percentage of fat was $4.17 \%$ in the morning period and $4.21 \%$ in the evening period, again the protein percentage was found as $3.42 \%$ and $3.44 \%$ in the morning and evening period, respectively (Niu and Harvatine, 2018). Froidmont et al. (2013) reported that the protein content was relatively stable as an absolute value, whereas the milk fat content decreased slightly as daily production increased, probably because the cows were fed more concentrate.

\section{CONCLUSION}

The effect of season was found to produce a highly significant effect on the fat, solid not fat and on the protein percentage present in milk; but there was no significant effect of season on the density of milk. Again, the effect of the period of milking was found to produce a highly significant influence on all the milk constituents described in our study. In the high humid environment of Assam, the Sahiwal breed was proved to be thriving well. The information of fat, protein, and SNF percentage in milk of Sahiwal can be used to create awareness towards the rearing of this outstanding milch breed. The idea of proper management and utilization of available resources would also help in the conservation of the Sahiwal breed at the farmers' level. Awareness amongst the farmers would help attract valuable consumers and spread the knowledge towards clean milk production.

\section{ACKNOWLEDGEMENTS}

The author is grateful to Dr. Purabi Kaushik, Major advisor for the constant help and guidance. The author will be ever grateful to Dr. R.N. Goswami, for providing a helping hand to analyze data successfully. Lastly, the author wishes to thank all the members as well as the required facilities available on the farm.

\section{REFERENCES}

Abraham, B.L. and Gayathri, S.L. 2015. Milk composition of crossbred and desi cattle maintained in the sub-tropical high ranges of Kerala. Ind. J. Vet. And Anim. Sci. Res., 44(1): 5355 .

Arora, R. and Bhojak, N. 2013. Physiochemical and environmental factors responsible for change in milk composition of milking animal. Int. J. Eng. And Sci., 2(1): 275-277.
Aslam, N., Abdullah, M., Fiaz, M., Bhatti, J.A., Iqbal, Z.M., Bangulzai, N., Choi, C.W. and Jo, I.H. 2014. Evaluation of different milking practices for optimum production performance in Sahiwal cows. J. Anim. Sci. Technol., 56(1): $1-5$.

Basic Animal Husbandry Statistics-2019. Department of Animal Husbandry and Dairying, Ministry of Fisheries, Animal Husbandry and Dairying, Krishi Bhawan, New Delhi.

Chakravarthi, M.K., Ekambaram, B. and Naik, B.R. 2017. Growth and production performance of Sahiwal cattle in Andhra Pradesh. Int. J. Sci. Env. Tech., 6(2): 1140-1142.

Froidmont, E., Mayeres, P., Picron, P., Turlot, A., Planchon, V. and Stilmant, D. 2013. Association between age at first calving, year and season of first calving and milk production in Holstein cows. Animal, 7(4): 665-672.

Harvey, W.R. 1975. Least-squares analysis of data with unequal subclass numbers, Technical report ARS H-4, U.S. Department of Agriculture, Agriculture Research Service.

Kramer, C.V. 1957. Extension of multiple range tests to group correlated adjusted means. Biometrics, 13(1): 13-18.

Niu, M. and Harvatine, K.J. 2018. Short communication: The effects of morning compared with evening feed delivery in lactating dairy cows during the summer. J. Dairy Sci., 101: 396-400.

Reddy, Y.R., Rao, K.S., Babu, D.S., Gangaraju, G., Sreedhar, S. and Reddy, K.V.B. 2015. Performance traits of Sahiwal and Jersey $\times$ Sahiwal crossbreds. Indian J. Anim. Prod. Mgmt., 31(3-4): 129-132.

Sourabh, Y., Kumar, C.S., Shankar, S.S. and Sudheer, J. 2017. Correlation between milk constituents and somatic cell counts in Holstein Friesian crossbred cattle. Int. J. Agric. Sci., 9(7): 3840-3842.

Swathi, Y., Reddy, Y.R., Babu, D.S. and Rao, D.S. 2017. Compositional quality of crossbred cow raw milk in rural and urban areas of YSR Kadapa district. Int. J. Environ. Sci. Te., 6(2): 1256-1259.

Talukder, M.A.I., Panandam, J.M., Halimatun, Y. and Idris, I. 2013. Milk composition and quality of Sahiwal-Friesian crossbred cow studied in Malaysia. The Agriculturists, 11(2): 58-66.

Thomas, M. and Sasidharan, M. 2015. Factors affecting milk fat percentage and solids-not-fat percentage and milk price of dairy cattle in humid tropics. Adv. Agric. Sci., 3(1): 11-17.

Tona, G.O., Oseni, S.O. and Adeyemo, B.Y. 2013. Morning, evening and entire lactation milk yield and composition of Jersey cows under hot and humid tropical environment of Nigeria. Int. J. Sci. Res., 5(6): 2324-2348. 